\title{
The trends of the antioxidant drug "U-74389G" on potassium levels during hypoxia reoxygenation injury in rats
}

\section{TSOMPOS 1 \\ C. PANOULIS ${ }^{2}$ \\ K. TOUTOUZAS 3 \\ A. TRIANTAFYLLOU 4 \\ G. ZOGRAFOS 5 \\ A. PAPALOIS 6 \\ ${ }^{1}$ Constantinos Tsompos: Consultant A Department of Obstetrics \& Gynecology Mesologi County Hospital, Etoloakarnania, Greece \\ ${ }^{2}$ Constantinos Panoulis: Assistant Professor Department of Obstetrics \& Gynecology Aretaieion Hospital, Athens University, Attiki, Greece \\ ${ }^{3}$ Konstantinos Toutouzas: Assistant Professor Department of Surgery, Ippokrateion General Hospital, Athens University, Attiki, Greece \\ ${ }^{4}$ Aggeliki Triantafyllou: Associate Professor Department of Biologic Chemistry, Athens University Attiki, Greece \\ ${ }^{5}$ George Zografos: Professor, Department of Surgery Ippokrateion General Hospital, Athens University Attiki, Greece \\ ${ }^{6}$ Apostolos Papalois: Director, Experimental Research Center ELPEN Pharmaceuticals, S.A. Inc., Co., Attiki Greece}

\section{Correspondence:}

Tsompos Constantinos

Department of Obstetrics \& Gynecology

Mesologi County Hospital

Nafpaktou street

Mesologi 30200

Etoloakarnania

Greece

E-mail: Tsomposconstantinos@gmail.com

Key words: hypoxia, U-74389G, potassium reoxygenation

Received October 26, 2015.

Revised March 21, 2016.

Accepted March 23, 2016

\section{Abstract}

Background: This experimental study examined the trends of the antioxidant drug " $U-74389 G$ ", on a rat model and particularly in a hypoxia - reoxygenation (HR) protocol. The trends of that molecule were studied biochemically using blood mean potassium levels.

Methods: 40 rats of mean weight $231.875 \mathrm{~g}$ were used in the study. Potassium $\left(K^{+}\right)$levels were measured at 60 min of reoxygenation (groups $A$ and $C$ ) and at 120 min of reoxygenation (groups $B$ and D) with administration of the drug $U-74389 G$ in groups $C$ and $D$.

Results: U-74389G administration non significantly decreased the $K^{+}$ levels by $2.14 \% \pm 5.06 \%(p=0.6730)$. Reoxygenation time non-significantly increased the $K^{+}$levels by $8.66 \% \pm 4.85 \%(p=0.0934)$. However, $U$ $74389 \mathrm{G}$ administration and reoxygenation time together non-significantly increased the $K^{+}$levels by $2.07 \% \pm 3.03 \%(P=0.4853)$.

Conclusions: U-74389G administration, reoxygenation time and their interaction have miscellaneous non significant short - term trends on potassium levels. Perhaps, a longer study time or a higher drug dose may reveal clearer and significant effects.

\section{INTRODUCTION}

Dermanent or transient damage with serious implications on adjacent 1 organs and systems may be due to tissue hypoxia reoxygenation (HR). The use of U-74389G in HR has been a challenge for many years. However, although the progress was significant, several practical questions have not been clarified yet. They include: a) how potent U-74389G should be b) when should it be administered and c) at what optimal dose U$74389 \mathrm{G}$ should be administered. The promising effect of U-74389G in tissue protection has been noted in several HR studies. U-74389G or also known as 21-[4-(2,6-di-1-pyrrolidinyl-4-pyrimidinyl)-1-piperazinyl]pregna-1,4,9(11)-triene-3,20-dione maleate salt is an antioxidant which prevents both arachidonic acid-induced and iron-dependent lipid peroxidation (1). It protects against $\mathrm{HR}$ injury in animal organs such as heart, liver and kidney models. These membrane-associating antioxidants are particularly effective in preventing permeability changes in brain microvascular endothelial cells monolayers (2).

The aim of this experimental study was to evaluate the effect of $U$ $74389 \mathrm{G}$ in a rat model of HR using mean blood potassium $\left(\mathrm{K}^{+}\right)$levels. The certain protocol and dose height were determined by following ex- 
Table 1: The U-74389G influence ( $\pm S D$ ) on the levels of some seric variables7 concerning reperfusion (rep) time

\begin{tabular}{|c|c|c|c|c|c|c|c|c|}
\hline Variable & 1h rep & p-value & $1.5 \mathrm{~h}$ rep & $\mathrm{p}$-value & $2 \mathrm{~h}$ rep & $\mathrm{p}$-value & $\begin{array}{l}\text { interaction of } \\
\text { U-74389G and rep }\end{array}$ & p-value \\
\hline WBCC8 & $+22.99 \% \pm 53.60 \%$ & 0.0914 & $+30.12 \% \pm 10.87 \%$ & 0.0050 & $+37.25 \% \pm 93.02 \%$ & 0.0212 & $+23.64 \% \pm 6.32 \%$ & 0.0003 \\
\hline RBCC & $+1.39 \% \pm 0.71 \%$ & 0.7161 & $+0.64 \% \pm 0.32 \%$ & 0.8106 & $-0.10 \% \pm 0.05 \%$ & 0.9762 & $+1.05 \% \pm 0.53 \%$ & 0.4911 \\
\hline Hematocrit9 & $+5.58 \% \pm 3 \%$ & 0.0852 & $+4.73 \% \pm 2.25 \%$ & 0.0435 & $+3.89 \pm 3.44 \%$ & 0.2608 & $+3.16 \% \pm 1.33 \%$ & 0.0196 \\
\hline Hemoglobin & $+5.2 \% \pm 2.8 \%$ & 0.0925 & $+3.9 \% \pm 2.1 \%$ & 0.0604 & $+2.7 \% \pm 3.2 \%$ & 0.3544 & $+2.5 \% \pm 1.3 \%$ & 0.0423 \\
\hline $\mathrm{MCH}$ & $+1.77 \% \pm 0.96 \%$ & 0.0663 & $+2.40 \% \pm 0.57 \%$ & 0.0001 & $+3.03 \% \pm 0.71 \%$ & 0.0003 & $1.33 \% \pm 0.36 \%$ & 0.0005 \\
\hline Platelet count2 & $-17.79 \% \pm 9.40 \%$ & 0.0647 & $-12.83 \% \pm 5.79 \%$ & 0.0303 & $-7.88 \% \pm 7.83 \%$ & 0.2939 & $-6.12 \% \pm 3.58 \%$ & 0.0857 \\
\hline Platelet-crit & $+3.80 \% \pm 9.87 \%$ & 0.6373 & $+9.23 \% \pm 6.29 \%$ & 0.1064 & $+14.66 \% \pm 9.03 \%$ & 0.0833 & $+6.72 \% \pm 3.73 \%$ & 0.0712 \\
\hline PDW & $+1.1 \% \pm 0.88 \%$ & 0.2368 & $+1.79 \% \pm 0.76 \%$ & 0.0314 & $+2.49 \% \pm 1.33 \%$ & 0.0807 & $+0.96 \% \pm 0.46 \%$ & 0.0396 \\
\hline Glucose & $-6.41 \% \pm 3.50 \%$ & 0.0663 & $-8.57 \% \pm 2.06 \%$ & 0.0001 & $-10.74 \% \pm 2.52 \%$ & 0.0003 & $-4.76 \% \pm 1.28 \%$ & 0.0005 \\
\hline Total protein & $-5.48 \% \pm 2.99 \%$ & 0.0663 & $-7.34 \% \pm 1.76 \%$ & 0.0000 & $-9.20 \% \pm 2.16 \%$ & 0.0000 & $-4.08 \% \pm 1.10 \%$ & 0.0000 \\
\hline ALP & $+22.66 \% \pm 12.37 \%$ & 0.0663 & $+31.91 \% \pm 7.69 \%$ & 0.0001 & $+41.16 \% \pm 9.65 \%$ & 0.0003 & $+17.75 \% \pm 4.79 \%$ & 0.0005 \\
\hline ACP & $-112.54 \% \pm 20.95 \%$ & 0.0006 & $-128.45 \% \pm 14.84 \%$ & 0.0000 & $-144.36 \% \pm 21.62 \%$ & 0.0000 & $-74.45 \% \pm 9.63 \%$ & 0.0000 \\
\hline CPK & $+54.32 \% \pm 13.75 \%$ & 0.0012 & $+35.34 \% \pm 17.20 \%$ & 0.0260 & $+16.37 \% \pm 30.24 \%$ & 0.4951 & $+18.52 \% \pm 9.44 \%$ & 0.0770 \\
\hline Sodium & $+1.22 \% \pm 0.66 \%$ & 0.0707 & $+0.17 \% \pm 0.61 \%$ & 0.7714 & $-0.87 \% \pm 1.03 \%$ & 0.3995 & $-0.32 \% \pm 0.36 \%$ & 0.3693 \\
\hline Chloride & $-0.58 \% \pm 0.77 \%$ & 0.4533 & $-0.97 \% \pm 0.53 \%$ & 0.0879 & $-1.36 \% \pm 0.76 \%$ & 0.1113 & $-0.75 \% \pm 0.38 \%$ & 0.0159 \\
\hline Calcium & $0 \% \pm 1.75 \%$ & 1 & $-0.14 \% \pm 1.10 \%$ & 0.8782 & $-0.28 \% \pm 1.54 \%$ & 0.8492 & $+0.14 \% \pm 0.64 \%$ & 0.8245 \\
\hline Phosphorus & $-2.23 \% \pm 5.51 \%$ & 0.7966 & $-1.61 \% \pm 3.32 \%$ & 0.5789 & $-1 \% \pm 4.48 \%$ & 0.8129 & $-1.09 \% \pm 2 \%$ & 0.5771 \\
\hline Magnesium & $+1.33 \% \pm 3.59 \%$ & 0.7033 & $-0.28 \% \pm 2.75 \%$ & 0.9171 & $-1.90 \% \pm 5.28 \%$ & 0.7161 & $+0.36 \% \pm 4.58 \%$ & 0.8228 \\
\hline Mean & $-1.31 \% \pm 31.71 \%$ & 0.2897 & $-2.22 \% \pm 34.31 \%$ & 0.2415 & $-3.11 \% \pm 37.99 \%$ & 0.3030 & $-0.85 \% \pm 20.13 \%$ & 0.1909 \\
\hline
\end{tabular}

periments with favorable outcomes. Actually, Flessas I et al found (3) the U-74389G protective in many emergency clinical situations of intestinal IR. Bimpis A et al limited brain damage itself after (4) U-74389G administration. Tsaroucha AK et al (5) attenuated liver damage after U74389G administration. Andreadou I et al protected the small intestine (6) after U-74389G administration. Along, ovarian TNF $\alpha$ and malondialdehyde levels were evaluated at the same endpoints. The levels of TNF $\alpha$ were stayed rather undisturbed; whereas the malondialdehyde levels were kept significantly increased. Nevertheless, the recommendation was that these 2 body mass related biomarkers not to be considered because they were not representative of all tissues under the ischemia level. Contrary, potassium is a systemic variable concerning all these tissues and not only the ovaries. The consequence of the applied treatment was the investigation of the short-term trends of U-74389G on general metabolism and certainly whether it is anabolic or catabolic. Table 1 depicts that after the evaluation of 18 seric variables, the shost-term trend of the drug is rather catabolic; without the potassium trend included. This table was built-up by the successive stepwise addition of published studies (7-9). Although the addition of every variable was incidental, it seems that the profil of the table and generally of the drug is improbable to change, as many other variables even if be added.

\section{MATERIALS AND METHODS}

\section{Animal preparation}

This basic experimental research was licensed by Veterinary Address of East Attiki Prefecture under 3693/1211-2010 \& 14/10-1-2012 decisions. All consumables, equipment and substances used, were a grant of Experimental Research Centre of ELPEN Pharmaceuticals Co. Inc. S.A. at Pikermi, Attiki. Accepted standards of humane animal care were adopted for Albino female Wistar rats. 7 days pre-experimental normal housing included ad libitum diet in laboratory. Post-experimental awakening and preservation of animals was not permitted even if euthanasia was required. Rats were randomly delivered to four experimental groups by 10 animals in each one, using following protocols of HR: Hypoxia for $45 \mathrm{~min}$ followed by reoxygenation for $60 \mathrm{~min}$ (group A). Hypoxia for $45 \mathrm{~min}$ followed by reoxygenation for $120 \mathrm{~min}$ (group B). Hypoxia for 45 min followed by immediate U-74389G intravenous (IV) administration and reoxygenation for $60 \mathrm{~min}$ (group C). Hypoxia for $45 \mathrm{~min}$ followed by immediate U-74389G IV administration and reoxygenation for $120 \mathrm{~min}$ (group D). The molecule U-74389G dosage was $10 \mathrm{mg} / \mathrm{Kg}$ body weight of animals.

Prenarcosis preceded of continuous intra-experimental general anesthesia, oxygen supply, electrocardiogram and 
Table 2: Weight and potassium mean levels and Std. Dev. of groups

\begin{tabular}{|lccc|}
\hline Groups & Variable & Mean & Std. Dev \\
\hline A & Weight & $243 \mathrm{~g}$ & $45.77724 \mathrm{~g}$ \\
& Potassium & $6.85 \mathrm{mmol} / \mathrm{l}$ & $0.8449194 \mathrm{mmol} / 1$ \\
B & Weight & $262 \mathrm{~g}$ & $31.10913 \mathrm{~g}$ \\
& Potassium & $6.82 \mathrm{mmol} / \mathrm{l}$ & $0.9507891 \mathrm{mmol} / 1$ \\
C & Weight & $212.5 \mathrm{~g}$ & $17.83411 \mathrm{~g}$ \\
& Potassium & $6.19 \mathrm{mmol} / 1$ & $0.3784471 \mathrm{mmol} / 1$ \\
D & Weight & $210 \mathrm{~g}$ & $18.10463 \mathrm{~g}$ \\
& Potassium & $7.23 \mathrm{mmol} / \mathrm{l}$ & $1.040353 \mathrm{mmol} / 1$ \\
\hline
\end{tabular}

Table 3: Statistical significance of mean values difference for groups (DG) after statistical paired t test application.

\begin{tabular}{|cccc|}
\hline DG & Variable & Difference & p-value \\
\hline A-B & Weight & $-19 \mathrm{~g}$ & 0.3555 \\
& Potassium & $0.03 \mathrm{mmol} / \mathrm{l}$ & 0.9483 \\
A-C & Weight & $30.5 \mathrm{~g}$ & 0.0674 \\
& Potassium & $0.66 \mathrm{mmol} / \mathrm{l}$ & 0.0789 \\
A-D & Weight & $33 \mathrm{~g}$ & 0.0574 \\
& Potassium & $-0.38 \mathrm{mmol} / \mathrm{l}$ & 0.3987 \\
B-C & Weight & $49.5 \mathrm{~g}$ & 0.0062 \\
& Potassium & $0.63 \mathrm{mmol} / 1$ & 0.0361 \\
B-D & Weight & $52 \mathrm{~g}$ & 0.0009 \\
& Potassium & $-0.41 \mathrm{mmol} / 1$ & 0.3905 \\
C-D & Weight & $2.5 \mathrm{~g}$ & 0.7043 \\
\end{tabular}

acidometry. Hypoxia was caused by laparotomic clamping inferior aorta over renal arteries with forceps for 45 min. Reoxygenation was induced by removing the clamp and reestablishment the inferior aorta patency. After exclusion of blood flow, the protocol of HR was applied, as described above for each experimental group. U-74389G was administered at the time of reoxygenation through inferior vena cava catheter. The $\mathrm{K}^{+}$levels were determined at 60th min of reoxygenation (for $\mathrm{A}$ and $\mathrm{C}$ groups) and at 120 th min of reoxygenation (for B and D groups). Fourty female Wistar albino rats were used (mean weight $231.875 \mathrm{~g}$ [standard deviation (SD): $36.59703 \mathrm{~g}$ ], with minimum weight $165 \mathrm{~g}$ and maximum weight $320 \mathrm{~g}$. Rats' weight could be potentially a confusing factor, e.g. more obese rats to have higher $\mathrm{K}$ levels. This assumption was also investigated.

\section{Control groups}

20 control rats (mean mass $252.5 \mathrm{~g}$ [SD: $39.31988 \mathrm{~g}$ ]) experienced hypoxia for $45 \mathrm{~min}$ followed by reoxygenation.

\section{Group A}

Reoxygenation lasted for $60 \mathrm{~min}$ ( $\mathrm{n}=10$ controls rats) mean mass $243 \mathrm{~g}$ [SD: $45.77724 \mathrm{~g}$ ], mean $\mathrm{K}^{+}$levels 6.85 $\mathrm{mmol} / \mathrm{l}$ [SD: $0.8449194 \mathrm{mmol} / \mathrm{l}$ ] (Table 2).

\section{Group B}

Reoxygenation lasted for $120 \mathrm{~min}$ ( $\mathrm{n}=10$ controls rats) mean mass $262 \mathrm{~g}$ [SD: $31.10913 \mathrm{~g}$ ], mean $\mathrm{K}^{+}$levels 6.82 $\mathrm{mmol} / \mathrm{l}$ [SD: $0.9507891 \mathrm{mmol} / \mathrm{l}$ ] (Table 2).

\section{Lazaroid (L) group}

$20 \mathrm{~L}$ rats (mean mass $211.25 \mathrm{~g}$ [SD: $17.53755 \mathrm{~g}$ ] experienced hypoxia for $45 \mathrm{~min}$ followed by reoxygenation in the beginning of which $10 \mathrm{mg}$ U-74389G/kg body weight were IV administered.

Group C

Reoxygenation lasted for $60 \mathrm{~min}(\mathrm{n}=10 \mathrm{~L}$ rats) mean mass $212.5 \mathrm{~g}$ [SD: $17.83411 \mathrm{~g}$ ], mean $\mathrm{K}^{+}$levels 6.19 $\mathrm{mmol} / \mathrm{l}$ [SD: $0.3784471 \mathrm{mmol} / \mathrm{l}]$ (Table 2).

Group D

Reoxygenation lasted for $120 \mathrm{~min}$ ( $\mathrm{n}=10 \mathrm{~L}$ rats) mean mass $210 \mathrm{~g}$ [SD: $18.10463 \mathrm{~g}$ ], mean $\mathrm{K}^{+}$levels $7.23 \mathrm{mmol} / \mathrm{l}$ [SD: $1.040353 \mathrm{mmol} / \mathrm{l}$ ] (Table 2).

\section{Statistical analysis}

Every weight and $\mathrm{K}^{+}$level group was compared with each other by statistical standard t-tests (Table 3). Any significant difference among $\mathrm{K}^{+}$levels, was investigated whether owed in probable significant weight correlations. 


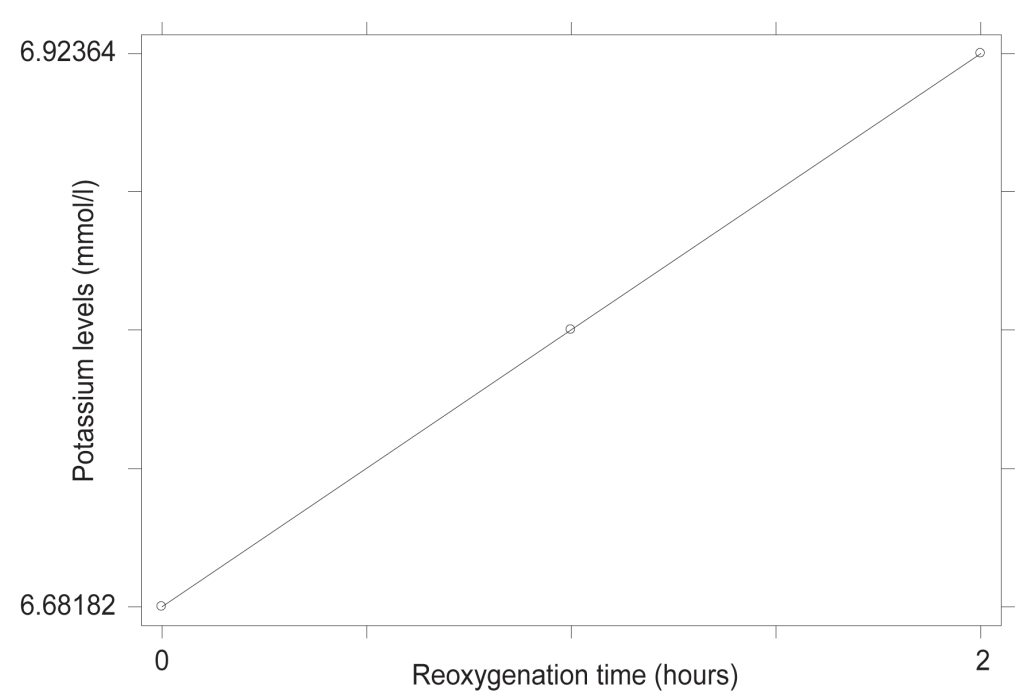

Figure 1: The increasing trend of $U-74389 G$ on potassium levels regarding reoxygenation time ( $p$-value $=0.4853$ ).

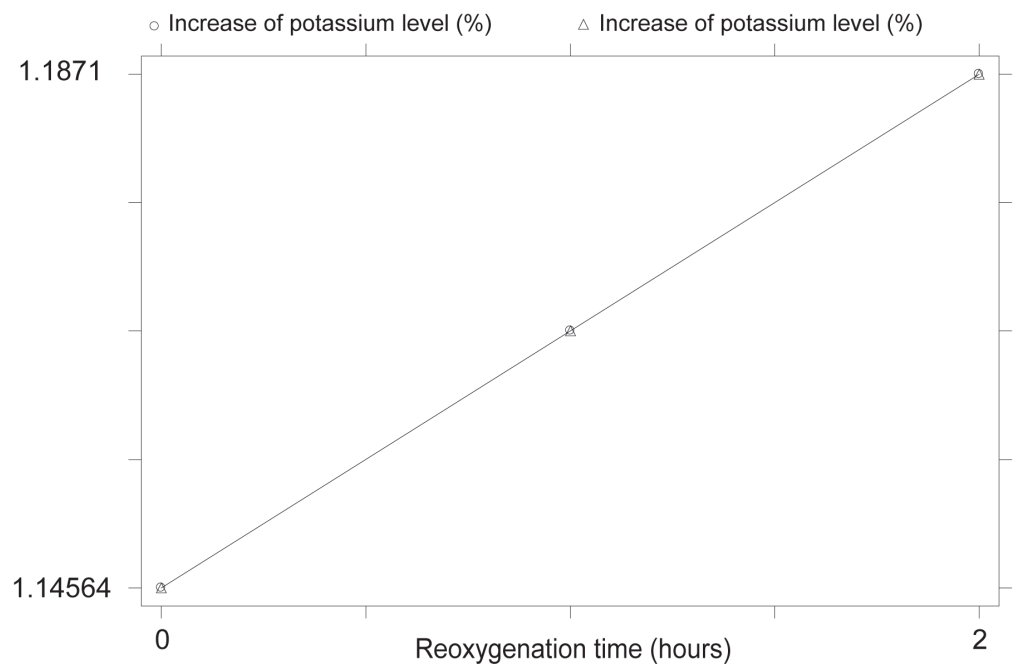

Figure 2: The (\%) increasing trend of U-74389G on potassium levels regarding reoxygenation time ( $p$-value=0.4853).

The generalized linear models (glm) with dependant variable the $\mathrm{K}^{+}$levels were applied. The 3 independent variables were the U-74389G or no drug, the reoxygenation time and both variables in combination. Inserting the rats' weight also as an independent variable at $\mathrm{glm}$ analysis, a non significant relation resulted in with $\mathrm{K}^{+}$ levels ( $\mathrm{p}=0.4029)$, so as to further investigation was not needed.

\section{RESULTS}

The application of glm analysis resulted in: U-74389G administration non significantly decreased the $\mathrm{K}^{+}$levels by $0.125 \mathrm{mmol} / \mathrm{l}[-0.7032406 \mathrm{mmol} / \mathrm{l}-0.4532407$ $\mathrm{mmol} / \mathrm{l}](\mathrm{P}=0.6641)$. This finding was in accordance with the results of standard $\mathrm{t}$-test $(\mathrm{p}=0.6820)$. Reoxygenation time non-significantly increased the $\mathrm{K}^{+}$levels by 0.505 $\mathrm{mmol} / \mathrm{l}[-0.0504671 \mathrm{mmol} / \mathrm{l}-1.060467 \mathrm{mmol} / \mathrm{l}](\mathrm{P}=$ $0.0735)$, also in accordance with standard t-test $(\mathrm{p}=0.1134)$. However, U-74389G administration and reoxygenation time together non-significantly increased the $\mathrm{K}^{+}$levels by $0.1209091 \mathrm{mmol} / \mathrm{l}[-0.2263983 \mathrm{mmol} / \mathrm{l}-0.4682165$ $\mathrm{mmol} / \mathrm{l}](\mathrm{P}=0.4853)$. Reviewing the above and table 3, the figures 1 and 2 sum up concerning the increasing trend of U-74389G in connection with reoxygenation time.

\section{DISCUSSION}

Bibliography lacks references concerning whether hypoxia can influence the potassium levels. Potassium levels influence $(10,11)$ multiple physiological processes, includ- 
ing resting cellular-membrane potential and the propagation of action potentials in neuronal, muscular, and cardiac tissue (12). Also K influences the hormone secretion and action, the vascular tone, controls the systemic blood pressure and the gastrointestinal motility. It joins in acidbase homeostasis, in glucose and insulin metabolism, in mineralocorticoid action, in renal concentrating ability and in fluid and electrolyte balance. Isolated potassium administration is impossible. The reason is that $\mathrm{K}^{+}$has a single electron in its outer electron shell, which readily gives it up to create an atom with a positive charge - a cation and oxidizes rapidly in air. After oxidation, it reacts vigorously with water combining with anions to form salts. Potassium occurs only in ionic salts usually associated with another drug or a factor. This last chemical conjugate probably influences the potassium occurrence. So, the administration of potassium is by means of a salt. Chiu PY et al associated (13) the inhibition of the mitochondrial permeability transition through the opening of mitochondrial $\mathrm{K}^{+}(\mathrm{ATP})$ channels, affording protection against myocardial ischemia reperfusion (IR) injury in rat myocardium. Kuhrt $\mathrm{H}$ et al found (14) that the expression of inwardly rectifying $\mathrm{K}^{+}$(Kir) currents and transient Atype $\mathrm{K}^{+}$currents alterations are characteristic features of retinal glial (Müller) cells after transient retinal IR. Nossaman BD et al associated (15) the vasodilator free radical peroxynitrite $\left(\mathrm{ONOO}^{-}\right)$with a cGMP-dependent mechanism in the hindlimb vascular bed of the cat. Pollesello $P$ et al have shown (16) that the protective vasodilatory and antiischemic effects are mediated via the opening of ATP-sensitive $\mathrm{K}^{+}$channels in vascular smooth-muscle cells and also in mitochondrial ATP-sensitive $\mathrm{K}^{+}$(mitoKATP) channels in heart. Chicco AJ et al (17) demonstrated that resistance to myocardial IR injury is dependent on sarcolemmal $\mathrm{K}^{+}$(ATP) activity during IR in rats. García González MJ et al associated (18) the vasodilatory effect with ATP-dependent $\mathrm{K}^{+}$channel $\mathrm{K}^{+}(\mathrm{ATP})$ opening properties in cardiogenic shock. Bittner $\mathrm{HB}$ et a combined (19) the post-transplant increased mortality rate by $40 \%$ with the low- $\mathrm{K}^{+}$dextran flush solution for the procurement of donor lungs. Reinés A et al found (20) that endogenous inhibitor endobain $\mathrm{E}$, was able to inhibit both enzyme activity and ligand binding on synaptosomal membrane $\mathrm{Na}^{+} \mathrm{K}^{+}$-ATPase activity, binding to cerebral IR cortex membranes in rats. Müllenheim J et al found that ischemic late preconditioning (ILPC) blocks (21) $\mathrm{K}^{+}$(ATP) channels and cardioprotection against prolonged ischemia in isolated cells of rabbits coronary IR. Reshef A et al (22) conferred protection against ATPdepleting crisis, opening the ATP-sensitive $\mathrm{K}^{+}$(ATP) channels in a model of primary rat IR neuronal cultures. Schmidt TA et al related the high concentration of $\mathrm{Na}^{+} \mathrm{K}^{+}$ATPase with large pressure work (23) in animal IR myocardium.

Also, $\mathrm{K}^{+}$levels are perhaps influenced by U-74389G administration. Stanimirovic DB et al abolished (24) the hydrogen peroxide-evoked decrease in Na,K-ATPase activity in presence of the steroid antioxidants U-74389G $(5-20 \mu \mathrm{M})$ in rats cerebromicrovascular endothelial cells (RCEC). The oxidant-induced inhibition of $\mathrm{Na}, \mathrm{K}-\mathrm{ATP}$ ase activity implicate the mechanism responsible for the delayed free radical-induced increase in RCEC membrane 'permeability'.

\section{CONCLUSION}

U-74389G administration, reoxygenation time and their interaction have miscellaneous non significant short - term trends on $\mathrm{K}^{+}$levels. Perhaps, a longer study time or a higher U-74389G dosage may reveal clearer and significant effects; including also an equal number of male rats for probable gender bias exclusion.

Acknowledgment: This study was funded by Scholarship by the Experimental Research Center ELPEN Pharmaceuticals (E.R.C.E), Athens, Greece. The research facilities for this project were provided by the aforementioned institution.

\section{REFERENCES}

1. https://www.caymanchem.com/app/template/Product.vm/cata$\log / 75860$.

2. SHI F, CAVITT J, AUDUS KL 1995 21-aminosteroid and 2-(aminomethyl)chromans inhibition of arachidonic acid-induced lipid peroxidation and permeability enhancement in bovine brain microvessel endothelial cell monolayers. Free Radical Biology and Medicine, 19(3), 349-357.

3. FLESSAS I, BRAMIS I, MENENAKOS E, TOUTOUZAS K, AGROGIANNIS G, PATSOURIS E, NONNI A, CHRYSIKOS D, KORONTZI M, GIOXARI A, ZOGRAFOS G, PAPALOIS A 2014 Effects of lazaroid U-74389G on intestinal ischemia and reperfusion injury in porcine experimental model. 13C: 42-48.

4. BIMPIS A, PAPALOIS A, TSAKIRIS S, ZARROS A, KALAFATAKIS K, BOTIS J, STOLAKIS V, ZISSIS KM, LIAPI C 2012 Activation of acetylcholinesterase after U-74389G administration in a porcine model of intracerebral hemorrhage. Metab Brain Dis. 27(2), 221-5.

5. TSAROUCHA AK, PAPALOIS A, VERNADAKIS S, ADAMOPOULOS S, PAPADOPOULOS K, LAMBROPOULOU M, CONSTADINIDIS T, KYRIAZI A, PAPADOPOULOS N, SIMOPOULOS C 2009 The effect of U-74389G on liver recovery after acute liver ischemia-reperfusion injury in a swine model. J Surg Res. 151(1), 10-4.

6. ANDREADOU I, POUSSIOS D, PAPALOIS A, GAVALAKIS N, ARONI K, GAZOULI M, GORGOULIS VG, FOTIADIS C 2003 Effect of U-74389G (21-lazaroid) on intestinal recovery after acute mesenteric ischemia and reperfusion in rats. In Vivo. 17(5), 463-8.

7. TSOMPOS C, PANOULIS C, TOUTOUZAS K, TRIANTAFYLLOU A, ZOGRAFOS G, PAPALOIS A. The effect of the antioxidant drug "U-74389G" on acid phosphatase levels during ischemia reperfusion injury in rats. Appl Med Res. Online First: 11 Mar, 2016. http://dx.doi.org/10.5455/amr.20160224103746

8. TSOMPOS C, PANOULIS C, TOUTOUZAS K, TRIANTAFYLLOU A, ZOGRAFOS G, PAPALOIS A 2016 The effect of the antioxidant drug "U-74389G" on white blood cells levels during 
hypoxia reoxygenation injury in rats. Asian Journal of Pharmacology and Toxicology. 4(13): 22-32.

9. TSOMPOS C, PANOULIS C, TOUTOUZAS K, ZOGRAFOS G, PAPALOIS A 2016 Acute Effect Of The Antioxidant Drug "U74389g" On Hematocrit Levels During Hypoxia and Reoxygenation Injury In Rats. Sci. Med. 26(1): 15-21.

10. MALNIC G, GIEBISCH G, MUTO S, WANG W, BAILEY MA, SATLIN LM 2013 Regulation of K+ excretion. In: Alpern RJ, Caplan MJ, Moe OW, eds. Seldin and Giebisch's the kidney: physiology and pathophysiology. 5th ed. London: Academic Press, 16591716

11. MOUNT DB, ZANDI-NEJAD K 2012 Disorders of potassium balance. In: Taal MW, Chertow GM, Marsden PA, Skorecki KL, Yu ASL, Brenner BM, eds. The kidney. 9th ed. Philadelphia: Elsevier, 640-688

12. LOCKLESS, S. W.; ZHOU, M.; MACKINNON, R 2007 "Structural and thermodynamic properties of selective ion binding in a K+ channel”. PLoSBiol5 (5): e121.

13. CHIU PY, WONG SM, LEUNG HY, et al 2011 Acute treatment with Danshen-Gegen decoction protects the myocardium against ischemia/reperfusion injury via the redox-sensitive $\mathrm{PKC} \varepsilon / \mathrm{mK}(\mathrm{ATP})$ pathway in rats. Phytomedicine. 18(11): 916-25.

14. KUHRT H, WURM A, KARL A, et al 2008 Müller cell gliosis in retinal organ culture mimics gliotic alterations after ischemia in vivo. Int J Dev Neurosci. 26(7): 745-51.

15. NOSSAMAN BD, BIVALACQUA TJ, CHAMPION HC, et al 2007 Analysis of vasodilator responses to peroxynitrite in the hindlimb vascular bed of the cat. J Cardiovasc Pharmacol. 50(4): 358-66.

16. POLLESELLO P, PAPP Z 2007 The cardioprotective effects of levosimendan: preclinical and clinical evidence. J Cardiovasc Pharmacol. 50(3): 257-63.
17. CHICCO AJ, JOHNSON MS, ARMSTRONG CJ, et al 2007 Sex-specific and exercise-acquired cardioprotection is abolished by sarcolemmal KATP channel blockade in the rat heart. Am J Physiol Heart Circ Physiol. 292(5): H2432-7.

18. GARCIA GONZALEZ MJ, DOMINGUEZ RODRIGUEZ A 2006 Pharmacologic treatment of heart failure due to ventricular dysfunction by myocardial stunning: potential role of levosimendan. Am J Cardiovasc Drugs. 6(2): 69-75. http://dx.doi. org/10.2165/00129784-200606020-00001

19. BITTNER HB, RICHTER M, KUNTZE T, et al 2006 Aprotinin decreases reperfusion injury and allograft dysfunction in clinical lung transplantation. Eur J Cardiothorac Surg. 29(2): 210-5.

20. REINES A, ZARATE S, CARMONA C, et al 2005 Endobain E, a brain endogenous factor, is present and modulates NMDA receptor in ischemic conditions. Life Sci. 78(3): 245-52.

21. MÜLLENHEIM J, RULANDS R, WIETSCHORKE T, et al 2001 Late preconditioning is blocked by racemic ketamine, but not by $S(+)$-ketamine. Anesth Analg. 93(2): 265-70.

22. RESHEF A, SPERLING O, ZOREF-SHANI E 1998 Opening of ATP-sensitive potassium channels by cromakalim confers tolerance against chemical ischemia in rat neuronal cultures. Neurosci Lett. 250(2): 111-4.

23. SCHMIDT TA, SVENDSEN JH, HAUNSØ S, et al 1990 Quantification of the total $\mathrm{Na}, \mathrm{K}-\mathrm{ATP}$ ase concentration in atria and ventricles from mammalian species by measuring $3 \mathrm{H}$-ouabain binding to intact myocardial samples. Stability to short term ischemia reperfusion. Basic Res Cardiol. 85(4): 411-27.

24. STANIMIROVIC DB, WONG J, BALL R, et al 1995 Free radicalinduced endothelial membrane dysfunction at the site of bloodbrain barrier: relationship between lipid peroxidation, $\mathrm{Na}, \mathrm{K}$ ATPase activity, and 51Cr release. Neurochem Res. 20(12): $1417-27$. 